\title{
Research on Innovations of Management Mechanisms under the Background of Shaanxi Free Trade Zone
}

\author{
Peng Zhang, a \\ ${ }^{1}$ Xi'an International University, Xi'an, 710077, China
}

Keywords: Shaanxi Free Trade Zone, Innovations of Management Mechanisms, Belt and Road

\begin{abstract}
At present, China's free trade zones have formed a gradual expansion of the coastal areas to the inland regions. Many free trade zones have formed a large number of replicable experiences, which provide valuable references for the construction of Shaanxi free trade zone. Learning the advanced experiences of Hubei free trade zone, Sichuan free trade zone and the Chongqing free trade zone, the paper explores the mechanism innovations of customs management, tax management, investment management and other aspects to provide some references for the relative researchers.
\end{abstract}

\section{Introduction}

"Free trade zone" refers to the multifunctional economic zone established in the territory of the border, with preferential taxation and special customs supervision policies as the main means, and trade liberalization and facilitation as the main purposes. Negative list management in the field of investment, trade facilitation, financial openness, innovation, strengthening, after the event supervision is an important feature of the free trade zone. It is another major opportunity in the history of Shaanxi's development. Shaanxi Free Trade Zone in Shaanxi will play an active role in "The Belt and Road", to the leading role of economic development in the northwest region, especially have an important impact on the reform and opening up new heights inland type building. The future, relying on the Shaanxi free trade area will be formed, including the global free trade area network important countries in five continents, the radiation of the neighboring countries and regions; promote international cooperation capacity, "The Belt and Road" is a smooth road, commercial road, the open road, the construction of a major thoroughfare, connecting the communication. Shaanxi free trade zone is mainly to implement the central authorities to better play a leading role in the construction of The Belt and Road, on the western development more open area portal to the west of the city, to create new heights inland and explore the reform and opening up," The Belt and Road along the country's economic cooperation and cultural exchanges new mode. In order to better promote the construction of free trade zone, Shaanxi will work closely with the economic zone of the Silk Road, opening to the west, the western development and the national energy strategy, the national cultural soft power construction based on the strategic needs of the country, closely around the inland, the national service strategy towards the world, the combination of opening and reform to improve the function and policy innovation, combining the basic institutional framework of the formation of the international investment and trade rules of convergence, to explore a new path can be replicated, effective for the development of the central and Western regions.

\section{Advanced Experiences of Innovations of Management Mechanisms of Free Trade Zones in Inland Regions of China}

Innovations of Management Mechanisms of Hubei Free Trade Zone. China Hubei Free Trade Zone continues to rely on the existing approved by the State Council, the new park, to continue the core on the system innovation, further docking high standards of international economic and trade rules, in a broader and broader range of the formation of distinctive, with emphasis on the pilot pattern, promote the comprehensive deepening reform and opening up. The country location of Hubei 
free trade zone is to implement the central government on the central region in order to undertake the transfer of industries, the construction of a number of strategic emerging industries and high-tech industrial base, its effect in the implementation of the strategy of central China and promote the demonstration of the role of the Yangtze River Economic Belt construction. Therefore, the core of the Hubei free trade zone is industry. Hubei has the convenient waterway transportation, the rich industrial base, the rich human capital, has to undertake the industry transfer each condition. In addition, Hubei also has a number of scientific research institutions, the overall strength of scientific research ranks among the nation. Therefore, Hubei has the necessary technological innovation, talent concentration and industrial upgrading necessary for the development of strategic emerging industries and high-tech industries. Basically, Hubei has formed a new industry and high-tech industry system which is dominated by optoelectronic information technology industry, high-end equipment manufacturing industry and new material industry. Therefore, based on the experience accumulated by the reform of the East Lake hi tech Zone in Wuhan, the negative list model of the Shanghai free trade zone will be extended to other areas of the Hubei free trade zone. Innovation to undertake domestic and foreign production transfer mode, strengthen industrial transfer, key undertaking construction. Relying on the national demonstration area of independent innovation in East Lake, we should promote institutional innovation, change the mode of innovation, and develop new industries and high-tech industries. Hubei free trade zone to actively undertake information technology, management consulting, engineering and other services outsourcing business.

Innovations of Management Mechanisms of Sichuan Free Trade Zone. The Sichuan Free Trade Zone shall establish a list of administrative powers and responsibilities according to the principle of equal responsibility and power, and define the boundaries of government functions. Deepening the reform of government institutions, exploring the establishment of statutory bodies, and promoting the transformation of relevant government institutions from direct provision of public services to the provision of third parties by contract management. Deepen the administrative examination and approval system reform, the maximum cancellation of administrative examination and approval items. Sichuan Free Trade Zone in Chengdu Tianfu New Area as the core, mainly implement the central authorities to increase efforts to open area west of the city and the construction of inland open portal strategy to support the requirements to build inland open economy heights, realize the inland and coastal border open cooperation. Chengdu is the gateway city of the western region, is the core of national innovation city comprehensive reform pilot area, Chengdu's economy, culture, transportation, science and technology has great influence in the southwest region, is one of the central city in southwest china. Inland open strategic support zone and inland open economy heights is the industry foundation of Sichuan rich human resources, good location and convenient traffic advantages, expand the opening of foreign trade development, the formation of China's coastal and border areas, along the different pattern of opening. Therefore, we can promote the construction of an innovation platform based on Tianfu New District and Chengdu hi tech Zone, and constantly explore new areas such as China, Britain, France, China, Germany and other international parks and capacity cooperation areas. Relying on the advantages of Chengdu's integrated transportation hub and the cost advantages of various factors, we will build a transit system in the inland areas and develop entrepot trade. Strengthen the linkage development and cooperation between regions as the center of Chengdu. Sichuan free trade zone perfect decision-making mechanism in accordance with the law, clear the scope and standards of major administrative decisions. Sichuan free trade zone to establish an administrative advisory system, the establishment of professional advisory committee composed of professionals for the free trade zone test area development advice.

Innovations of Management Mechanisms of Chongqing Free Trade Zone. China Chongqing free trade experiment zone is a regional free trade zone established by the Chinese government in Chongqing. Chongqing is the only municipality directly under the central government in central and Western china. The national strategic positioning of Chongqing free trade zone is mainly about the implementation of the central and Chongqing play an important role of strategic fulcrum connection point, to increase efforts to open the portal area to the west of the city, promote western development strategy thorough implementation. Chongqing is an important strategic fulcrum, Silk Road Economic 
Belt the western hub of the Yangtze River economic belt and the maritime Silk Road economic hinterland, is an important link between China's western city, in Belt and Road Initiative and connection point of the Yangtze River economic belt, the advantage is obvious; the "Western gateway city" refers to Chongqing in the west of China especially in the central city in Southwest China and the entry of foreign exchanges, transportation is convenient, economic development, infrastructure improvement, has great radiation and influence on the southwest region; the "western development" strategy provides a historical opportunity for the development of Chongqing, in-depth implementation of the western development strategy, give full play to Chongqing radiation and influence. Make full use of the golden waterway of Yangtze River and the Chongqing New Europe international railway transport channel, international logistics center construction in China inland; Chongqing strategic play Internet demonstration projects and the agglomeration effect, the development of financial services, aviation, transport and logistics, and information and communication technology and other key areas of cooperation; in Chongqing free trade zone as a base, the development of import and export processing trade, construction of radiation inside and outside of the international trading system. After three to five years of reform and exploration, efforts to build an international logistics hub and port heights, to promote the construction of the western region, a comprehensive opening of the new pattern of urban portal, and promote the implementation of the strategy of the western development.

\section{Innovations of Management Mechanisms under the Background of Shaanxi Free Trade Zone}

Innovations of Customer Management Mechanisms. The business will certainly free trade zone involving different departments, but also as the special supervision of the regional free trade area, and area difference, so as to implement such multi area window way, it does not reflect the institutional advantages of the fta. Therefore, in foreign management, we can implement a single window model to solve the long-standing shortcomings of our country: more windows and complicated procedures, not only the cost is relatively large, but also manpower and energy consumption. free trade zone test area to implement a declaration, a check, a release mode, greatly reducing management costs. Strengthen coordination and cooperation between customs and other departments in order to ensure national stability and maintain economic security. The main role to play customs supervision, in collaboration with the relevant departments of the State Council, strictly examine the monopolistic behavior of operators, on the implementation of monopoly operators punished. At the same time, it is necessary to strengthen cooperation among customs, quality inspection, industry and Commerce and management departments. However, there is still no information sharing system among these departments, which brings difficulties to cooperation. Therefore, as soon as possible to overcome technical problems, accelerate the improvement of unified regulatory mechanism, explore the establishment of a unified electronic purse fence management, the establishment of risk control customs supervision and management mechanism. Collaborative monitoring with other departments can improve the efficiency of customs supervision, reduce regulatory risks, and make every effort to reduce regulatory loopholes. Establish and improve the macro management mechanism for deepening the reform of the free trade area. In the trade regulatory system innovation at the same time, the synchronous change of free trade zone to actively explore the customs business management mechanism, further integration of management resources in different regions to realize intensive management, integration. Establish the internal management mechanism of customs which is compatible with the reform and innovation goals. Establish a sound and unified free trade zone test area, deepen reform and coordination mechanism.

Innovations of Tax Management Mechanisms. From the perspective of regional competition, tax preferential policies to the regional preferential policy, regional preferential the between group harmonic area between the gap, but the current policy bias in economically developed areas, actually formed a reverse adjustment. From the perspective of industry competition in the current preferential tax policy also shows a preferential individual characteristics and tendency are actually the monopoly of the industry, undermines the competitive environment, also affected the taxpayers as consumers of 
consumer preferences, as competitors against other competing interests of taxpayers. In recent years, on the one hand, more and more preferential tax policies have been introduced. To encourage the development of the country, it is necessary to introduce appropriate tax incentives. On the other hand, there are many calls from different regions, industries and enterprises to introduce preferential tax policies. Tax incentives seem to be the master key. To some extent, these Provisions have been beyond the essence of tax incentives, there is suspicion of the use of tax incentives to achieve the purpose of administrative monopoly, not only will dismember the tax base, the impact of revenue stability, but also had a distorted effect on the behavior of enterprises as the main body of the market. When the marginal cost of the government to encourage the development of product or industry producers is greater than the marginal social benefit is complemented by the product or the industry to generate the incentive effect of tax incentives would inevitably bring about changes in two aspects. On the one hand, the established producers of this product or industry will certainly increase investment and expand production scale. On the other hand, the production of other products or industries is likely to involve production factors under sufficient interest inducing mechanisms. This enables the government's goals to be realized, thereby promoting the transformation of trade development in the free trade zone. This is the rational basis for the implementation of preferential tax policy in the free trade zone.

Innovations of Investment Management Mechanisms. Under the premise of controllable risks, we can try to create conditions for the convertibility of RMB capital account, the marketization of interest rates in financial markets and the cross-border use of RMB in the experimental area. In the experimental area, the price of the assets of the financial institutions shall be subject to market pricing. If these measures are truly implemented, the transaction costs of enterprises in the free trade zone will be substantially reduced, and valuable experience will be provided for the convertibility of the RMB capital account and the marketization of the market. In the first-tier cities, innovative regulatory techniques and methods to simplify the entry and exit list, simplify international transit, assembly, and distribution and other business procedures. In the second-tier cities, the implementation of convenient access, and strictly guard against quality and safety risk inspection and quarantine supervision mode. We carry out effective supervision through risk monitoring, third party management, margin requirements and so on. Government approval in advance by the focus to improve the information network platform for attention to the matter, after regulation of acceptance, approval of a comprehensive and efficient operation of the service mode, the realization mechanism of collaborative management in different departments to improve administrative transparency, improve the information disclosure mechanism and effectively protect the interests of investors, to allow qualified foreign investors free transfer the investment income. These administrative innovations can help transform government functions and innovate government management. Negative list refers to the country in the introduction of foreign investment in the process of some national treatment is inconsistent with the management measures, in the form of a list of publicly listed. Foreign investment shall not be allowed to invest or restrict investment as long as the items listed in the list are prohibited or restricted. The list has no or no restrictions, and foreign investment can be made.

\section{Conclusion}

The approval of Shaanxi free trade zone is to promote economic and social development of Shaanxi. However, the free trade zone is a new thing for the province. Under Belt and Road Initiative background, Shaanxi free trade zone should strive to learn from the advanced experience from the free trade zones in China to carry out the innovation of management mechanism to build a free trade zone area with a demonstration significance in China. 


\section{References}

[1] Lu Zhigang, Zhang Congli. Impact of the Eastern Free Trade Zone on the Economic Development of the Western Region [J]. China Development, 2015, 15(5): 20-24.

[2] Wang Quanxing, Wang Fengyan. On Institutional Innovation of Social Organization Constructionin Chinese Free Trade Zone [J]. Journal of Shanghai University of Finance and Economics, 2014, 16(3): 4-11+37.

[3] Fang Lei, Zong Gang, Chu Xuxin. Research on Construction Model of Free Trade Zone in Inland Regions of China [J]. Academic Journal of Zhongzhou, 2016(1): 31-35.

[4] Sun Jiuwen, Tang Zeli. Research on the Path of Constructing FreeTrade Zones in Bordering and Inland Regions of China [J]. Shanghai Journal of Economics, 2016(10): 100-107+115. 